\title{
関西の夏の味覚であるハモは、ウナギ目魚類の 新たな実験モデルになるか?
}

小林 靖尚 (近畿大学 農学部 水産学科 水産生物学研究室) E-mail: yasuhisa@nara.kindai.ac.jp

\section{1.はじめに}

学会員の皆様には実験モデルとして馴染み深い魚であ るニホンウナギ Angullia japonicaは、飼育下では性的に 未熟なままで産卵を行わない事や、自然界で未だに産卵 行動が観察されていない事などから、生殖生理、生殖生

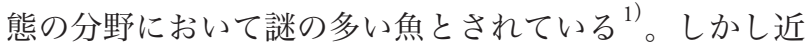
年、多くの優秀な研究者達の長年の努力によって、天然 資源に頼らないウナギの完全養殖技術が確立され2)、産 卵地が遠く外洋 (マリアナ諸島西方海域)にあることな ぞが明らかにされる゙ など、ウナギの生殖に関する詳細 な知見が集積しつつある。私自身はウナギを用いた研究 を行った事はないが、ウナギを成熟させるためにホルモ ンを苦心して調製・投与する先輩研究者達を横目で見な がら、大変そうだなと実感したものである。

本稿では、ウナギ目に属する八モMuraenesox cinereus の瀬戸内海における生殖生態について書かせていただこ うと思う。

\section{2. ハモとの出会い}

私は2012年に、沖縄から岡山大学の理学部附属臨海 実験所に異動した。着任当初、今後の実験対象魚種につ いて悩んでいた。そのような折に、近隣にある岡山県の 水産試験場に勤務する元谷剛さんから「漁船を 1 日チャ ーターして、瀬戸内海に棲息する魚類の資源量を調査す るので見学しますか?」とのありがたい申し出があった。 二つ返事で調査に参加させて頂き、実験所近くの漁港か ら底引き網漁船に乗り込んだ。当日は、何度か揚げられ る網の中に、大小さまざまな魚種が確認され、嬉々とし て船上で魚の仕分けを手伝った (写真 $1 \mathrm{~A})$ 。その際、漁 師さんに、うかつに手を出すと鋭い歯に噛まれて危ない と注意を受けたのが、船上で激しく動く数多くの「八モ」 だった(写真 $1 \mathrm{~B}, \mathrm{C})$ 。その時まで私は、八モというのは 京都料理に欠かせない高級食材であり、簡単に漁獲され るような魚ではないと浅はかな認識をしていた為、その 日の大漁の八モを見て驚いたことを鮮明に覚えている。

\section{3. 瀬戸内海におけるハモの産卵生態について}

調査終了後、船上で仕分けしたさまざまな魚を分けて いただき、クーラーボックスに入机実験所に運んだ。次 に、それらの魚の生殖腺形態を観察してみた。その際、 八モの生殖腺もウナギと同じようにヒモのような未熟な 状態だろうと勝手に予想し、いただいた八モの開腹をし たところ、体内には、はち切れんばかりに成熟した卵巣
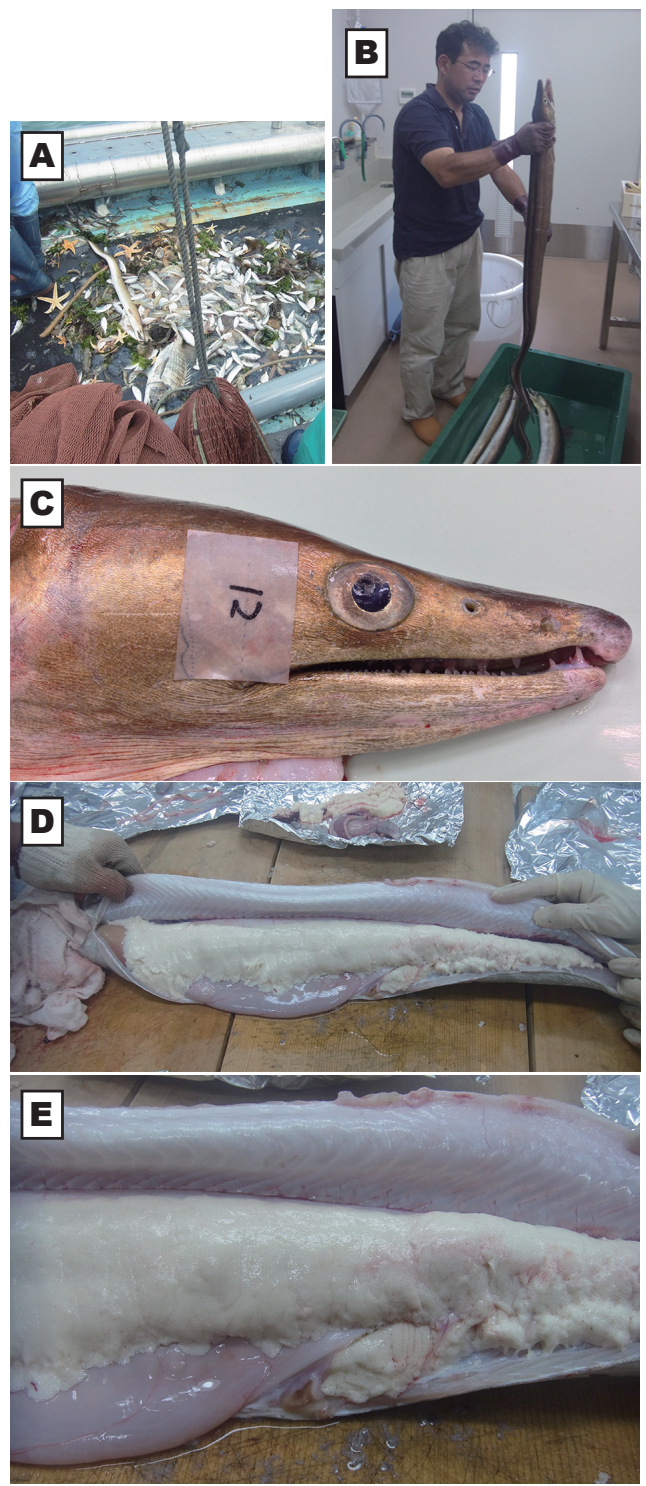

写真1 瀬戸内海のハモ

(A) 底引き網で取れた魚たち。(B) ハモのサンプリング風景。 (C) 八モの頭部。鋭い歯が観察される。(D) 八モの発達した 卵巣。(E) 写真 D の拡大図。発達した卵母細胞が観察される。

が観察された(写真1D, E)。組織切片にして顕微鏡で観 察するまでもなく、卵は一粒一粒が非常に大きく、八モ の産卵が間近であることが強く示唆された。そのため八 モは、同じウナギ目の魚であるウナギやアナゴと異なり、 遠くの外洋で産卵をするのではなく、近くの海で産卵し ていることが十分に予想された。

再び自分の浅はかさに呆れながらも、次に八モに関す 
るこれまでの知見を調べてみた。その結果、八モに関す る論文はウナギやアナゴに比べ非常に少なく、遺伝子の 登録数に至っては数えるほどだった。この理由は、八モ の産業的価值がウナギやアナゴに比べて低いためだと考 えられたが、同じウナギ目の魚なのに、八モの学術的な 知見が少ないのは何とも勿体なく感じた。そこで、少な くとも「八モの成熟個体が瀬戸内海に棲息している事実」 を内外に示すべきだと考元、水産試験場の元谷さんに相 談し、賛同いただいた。また水産試験場の皆さんも、瀬 戸内海で最近、アナゴの漁獲量が急減している代わりに、 八モの漁獲量が急増している事実 ${ }^{4)}$ があることから、ハ モに興味を持っていた。

以上の経緯から八モ研究を始動させることになった。 最初に、瀬戸内海に棲息する八モの産卵周期を明らか にする事を目的として、6月から 10 月に掛けて定期サン プリングを行い、メスの卵巣状態を観察した。その結果、 八モの卵巣には発達段階の異なる卵母細胞が同時に存在
する事が明らかとなり、八モは産卵期の間に複数回の排 卵を行う多回産卵魚であることがわかった (写真2)。次 に7月9日にサンプリングした全ての個体において核移 動期の卵母細胞が認められた。加えて、GSI (生殖腺重 量 /体重 $\times 100$ )のピークも認められた（図1)。さらに血 漿中の性ステロイドホルモン（エストロゲンとアンドロ ゲン)のピークも7月9日の実験群に認められた。以上 の結果から、瀬戸内海の八モの産卵期は7月上旬から中 旬であることが明らかになった。また八モは雌雄で生息 場所を棲み分けている可能性も示唆されている。今後は、 より詳細なハモの生殖に関するデー夕を蓄積しょうと考 えて、次世代シークエンサーを用いた八モ脳下垂体のト ランスクリプトーム解析を始めたところである。他にも バイオロギングの手法を取り入れ、瀬戸内海における八 モの産卵地の特定および産卵行動を観察してみたいとも 考えている。
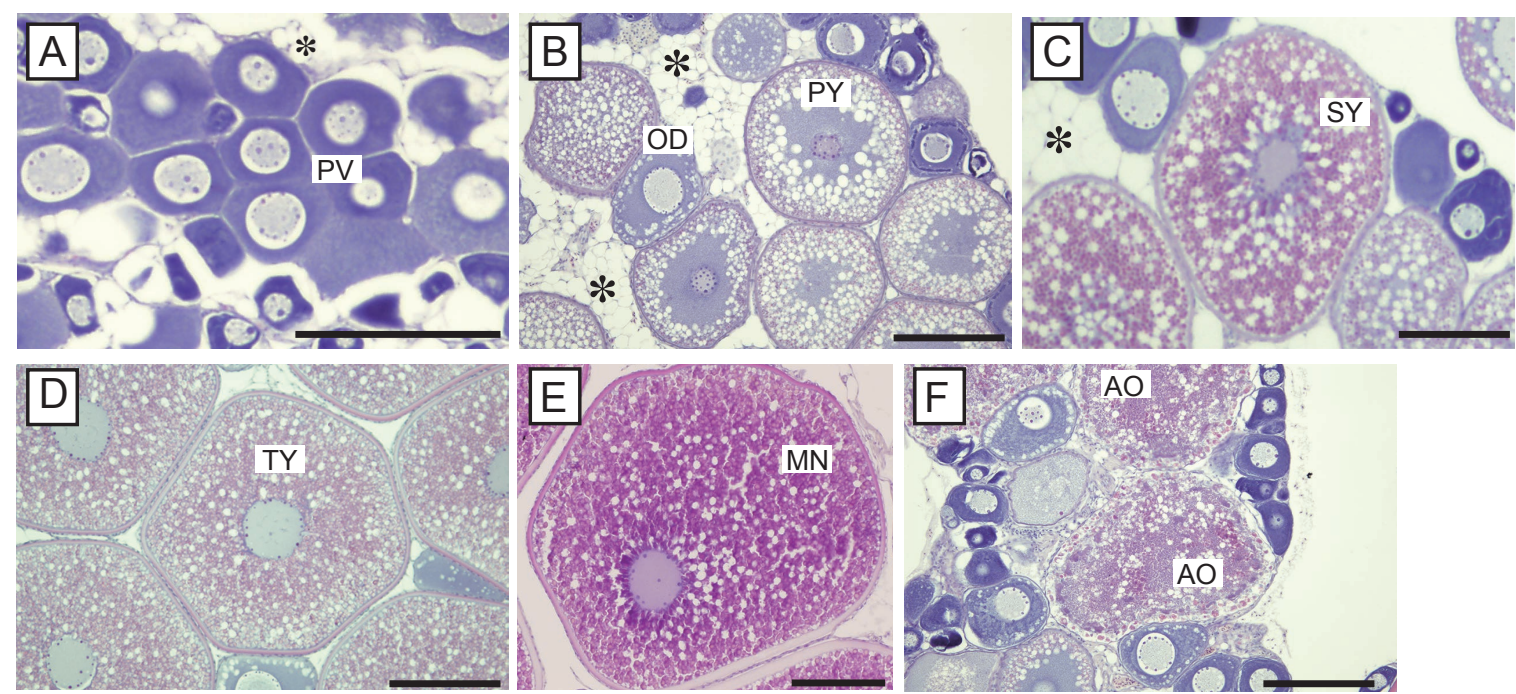

写真2 八モ卵母細胞の発達段階

(A) 周辺仁期 (PV)。アスタリスクは脂肪細胞。(B) 油球期 (OD) と第一次卵黄球期 (PV)。(C) 第二次卵黄球期 (SY)。 (D) 第三次卵黄球期 (TY)。(E) 核移動期 (MN)。(F) 崩壊卵 (AO)。バーは全て $200 \mu \mathrm{m} 。$

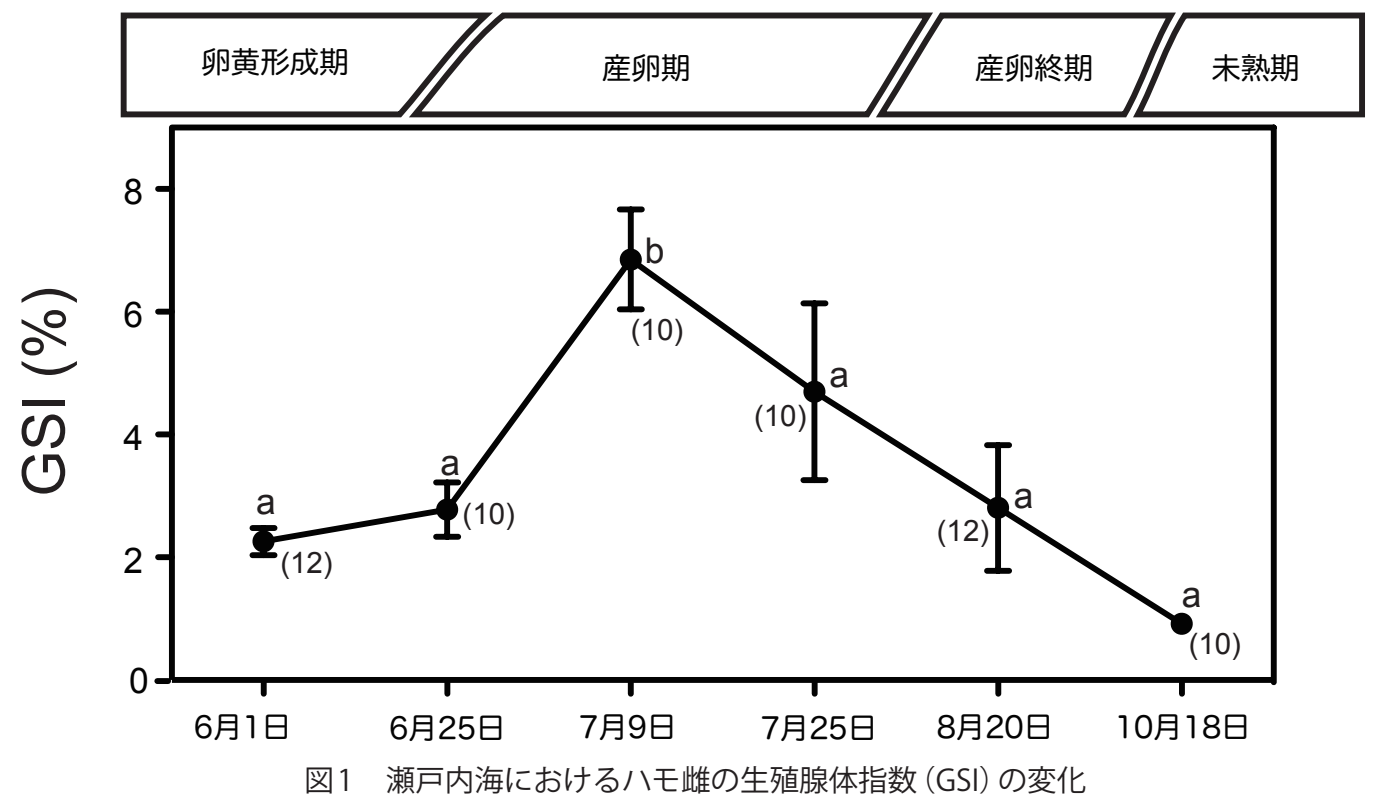




\section{4. 今後のハモ研究の位置づけ (ウナギ目の新たな実験 モデル)}

上記の私が行ってきた八モに関する研究は、基礎的な 解析が主で、特に目新しい結果が含まれているわけでは ない。つまり、まだ漁業者が経験的に知っているレベル である。しかし、こ机らの結果を学会・論文発表した ところ、他の水産研究者から「たしかに八モを水槽に入 れておくと勝手に産卵した」との話を聞くことができた。 今後は「産卵する八モ」と「産卵しないウナギ」の生殖生 理学的知見を比べることにより、飼育下で何故ウナギは 成熟/産卵しないのか？という長年の疑問に対して、異 なる視点から新たな知見を提供できると考えている。ま た、これまでウナギ研究で培われたさまざまな実験手技 (カニュレーション手術、ホルモン投与、バイオロギン グ等) は、変更なくそのまま八モに応用することが可能 であるため、八モ研究を発展させていくのは、思ったよ りも容易なのではと、これまた浅はかに妄想している。

本稿に関する詳しい内容は「Kobayashi Y, et al. Basic reproductive biology of daggertooth pike conger, Muraenesox cinereus: A possible model for oogenesis in Anguilliformes. Zool lett, 1:25」を参照して頂ければ幸いである。

\section{5. おわりに}

最後に私事だが、今春、私は慣れ親しんだ岡山大学臨 海実験所から、マグロの完全養殖で有名な近畿大学農学 部水産学科に異動した。赴任して数ケ月が経ったが、未 だに何の設備もない部屋で今後の研究をどうするかに不 安を抱くと共に、これまでの私の研究環境がいかに恵ま れていたのかを実感する毎日を過ごしている。今後は、 学会員の皆様の御協力を賜孔るように、早々に設備を整 え、なんとか良い研究を行いたいと考えているので、ご 指導ご鞭撻の程よろしくお願いします。

末筆ながら、まだまだ始まったばかりで、それほど大 きな成果が出ていない八モの研究にも関わらず、興味を 抱いて頂き、本稿の執筆機会を与えてくださった広島大 学の浮穴先生に感謝申しあげる。

\section{文 献}

1 ) 香川浩彦。海洋と生物, 23, 130-136 (2001).

2) Tanaka H, et al. Fish Physiol Biochem, 28, 493-497 (2003).

3 ) Tsukamoto K, et al. Nat Commun, 2, 1174 (2011).

4) Watari S, et al. Fish Sci, 79, 367-373 (2013).

\section{複写を希望の方へ}

本誌に記載された著作物の複写をご希望の方は、(社) 学術著作権協会より許諾を受けて下さい。曰本比較内分泌 学会は本誌掲載著作物の複写に関する権利を(社) 学術著作権協会に委託しております。但し、企業等法人による 社内利用目的の複写については、当該企業等法人が (社) 日本複写権センターと包括複写許諾契約を締結している 場合には、その必要はありません（社外領布目的の複写については許諾が必要となります）。

権利委託先：干107-0052 東京都港区赤坂9-6-41 乃木坂ビル3F

一般社団法人 学術著作権協会

FAX : 03-3475-5619 E-mail : info@jaacc.jp

なお、複写以外の著作物の引用・転載・翻訳等の許諾に関しては、直接、日本比較内分泌学会事務局にお問い合 わせ下さい。

干 277-8564 千葉県柏市柏の葉5-1-5 東京大学大気海洋研究所生理学分野

日本比較内分泌学会事務局 兵藤 晋

Tel : 04-7136-6202 Fax:04-7136-6206 E-mail : hyodo@aori.u-tokyo.ac.jp

\section{Notice about photocopying for overseas user}

In order to make a copy of any work from this publication, users must obtain permission from the Japan Academic Association for Copyright Clearance (JAACC) or the local Reproduction Rights Organizations (RROs) under bilateral contract with JAACC (see "List of foreign bilateral agreements" on the following website).

Japan Academic Association for Copyright Clearance (JAACC)

Akasaka 9-6-41, Minato-ku, Tokyo 107-0052, Japan

Website: http://www.jaacc.jp

E-mail: info@jaacc.jp Fax: +81-3-3475-5619

In case of quotation, reproduction and translation, please contact the copyright holder (JSCE) directly.

Japan Society for Comparative Endocrinology (JSCE)

Susumu Hyodo, Ph.D

Laboratory of Physiology, Atmosphere and Ocean Research Institute, University of Tokyo

5-1-5 Kashiwanoha, Kashiwa, Chiba 277-8564, Japan

E-mail : hyodo@aori.u-tokyo.ac.jp Fax : +81-4-7136-6206 